Int. J. Dev. Biol. 53: 203-214 (2009)

doi: $10.1387 / \mathrm{ijdb} .082741 \mathrm{ki}$

\title{
Interplay between DNA methylation, histone modification and chromatin remodeling in stem cells and during development
}

\author{
KOHTA IKEGAMI ${ }^{1, \#, ~ J U N ~ O H G A N E ~}{ }^{1}$, SATOSHI TANAKA ${ }^{1}$, SHINTARO YAGI ${ }^{1}$, \\ and KUNIO SHIOTA*,1,2 \\ ${ }^{1}$ Laboratory of Cellular Biochemistry, Animal Resource Sciences / Veterinary Medical Sciences, Graduate School of Agriculture and Life \\ Sciences, The University of Tokyo, Tokyo and ${ }^{2}$ Organ Development Research Laboratory, National Institute of Advanced Industrial \\ Science and Technology (AIST), Tsukuba-city, Japan
}

\begin{abstract}
Genes constitute only a small proportion of the mammalian genome, the majority of which is composed of non-genic repetitive elements including interspersed repeats and satellites. A unique feature of the mammalian genome is that there are numerous tissue-dependent, differentially methylated regions (T-DMRs) in the non-repetitive sequences, which include genes and their regulatory elements. The epigenetic status of T-DMRs varies from that of repetitive elements and constitutes the DNA methylation profile genome-wide. Since the DNA methylation profile is specific to each cell and tissue type, much like a fingerprint, it can be used as a means of identification. The formation of DNA methylation profiles is the basis for cell differentiation and development in mammals. The epigenetic status of each T-DMR is regulated by the interplay between DNA methyltransferases, histone modification enzymes, histone subtypes, non-histone nuclear proteins and non-coding RNAs. In this review, we will discuss how these epigenetic factors cooperate to establish cell- and tissue-specific DNA methylation profiles.
\end{abstract}

KEY WORDS: epigenetics, DNA methylation, T-DMR, histone modification, chromatin remodeling

\section{Epigenetic systems in mammalian development}

In unicellular organisms, each individual cell uses almost all of the genomic information and displays an essentially identical phenotype. In contrast, in mammals there are at least a few hundred different cell types based on a variety of physiological and morphological criteria. All of these cell types are derived from a single fertilized egg. The differentiation of each cell type is achieved without changes in DNA sequence, but through the coordinated utilization of subsets of genes. In order to achieve the proper temporal and spatial regulation of these genes throughout development, a set of epigenetic mechanisms are employed, which includes histone modifications and DNA methylation (Shiota, 2004; Lieb et al., 2006).

In mammals, DNA methylation occurs through DNA methyltransferases (Dnmts) that operate within 5'-CG-3' dinucle- otide (CpG: C followed by G). 5-Methylcytosine (5-MeC) is the only chemical modification of mammalian genomic DNA. The status of methylated $\mathrm{CpGs}$ is maintained after DNA replication by Dnmts and therefore is heritable through cellular generations (Bird, 2002). 5-MeC is found in most eukaryotic DNA including fungi, plants and vertebrates (Bird, 2002). The prototype Dnmt is found in unicellular organisms such as Escherichia coli. The Dnmt genes are conserved among most of eukaryotes, however 5-MeC is absent or rare in the yeast species (Saccharomyces cerevisiae, Saccharomyces pombe), fly (Drosophila melanogaster) and nematodes (Caenorhabditis elegans, Pristionchus pacificus) due to

\footnotetext{
Abbreviations used in this paper: 5-MeC, 5-methylcytosine; Dnmt, DNA methyltransferase; E, embryonic day; ES, embryonic stem cell; nt, nucleotide; T-DMR, tissue-dependent differentially methylated regions.
}

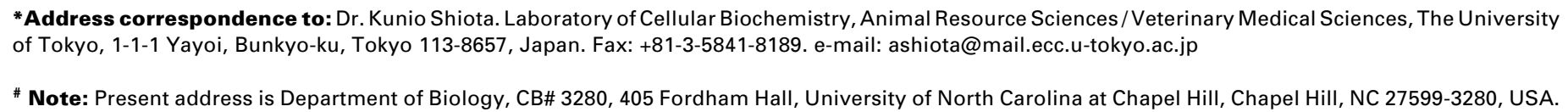

Note: We use NCBI official symbols for protein or gene names unless otherwise noted (http://www.ncbi.nlm.nih.gov/sites/entrez).

Published online: 28 April 2009.

ISSN: Online 1696-3547, Print 0214-6282 
deletion of the gene or mutations that severely affect the enzymatic activity (Goll and Bestor, 2005). Therefore, the adoption and/or maintenance of the DNA methylation system may be a key molecular event in evolution for species divergence and the emergence of vertebrates.

Histone modifications are another form of epigenetic regulation, which refers to post-translational modifications to the $\mathrm{N}$ terminal tails of the histone. Thus far, over 60 different residues on the core histones $(\mathrm{H} 2 \mathrm{~A}, \mathrm{H} 2 \mathrm{~B}, \mathrm{H} 3$, and $\mathrm{H} 4)$ have been reported to be modified. The modifications include acetylation, methylation, phosporylation, ubiquitination, sumoylation, ADP ribosylation, deimination, and proline isomerization (Kouzaridez, 2007). Several histone modifications serve to coordinate the set of 5-MeC. These epigenetic marks are generally associated with chromatin condensation, which plays a crucial role in silencing genes, stabilizing chromosomal structure, and suppressing the mobility of retrotransposons.

Cellular differentiation involves massive alterations of the genome-wide epigenetic status of multiple gene loci, with changes in both de novo methylation and demethylation of DNA and in various histone modifications (Ohgane et al., 2002; Shiota et al., 2002; Eckhardt et al., 2006; Bracken et al., 2006; Squazzo et al., 2006; Oakes et al., 2007; Mikkelsen et al., 2007). There are, indeed, numerous tissue-dependent, differentially DNA-methylated regions (T-DMRs) in the unique sequences including genes and their regulatory elements in the mammalian genome.

In this review, we describe 1) the concepts of the DNA methylation profiles of T-DMRs in normal cells and tissues, and 2) the interplay among epigenetic factors in forming the DNA methylation profiles specific to different cell types.

\section{Tissue-dependent, differentially methylated regions ( $T$ - DMRs) in unique sequences in the mammalian genome}

\section{DNA methylation in repetitive and unique sequences}

A remarkable feature of the mammalian genome is that a large portion is composed of non-genic, repetitive elements including interspersed repeats and satellites: $49 \%$ and $44 \%$ in the human (hg18 assembly) and mouse (mm9 assembly) genome respectively (Repeatmasker; http://www.repeatmasker.org/). Over 60\% of the $\mathrm{CpGs}$ of the mouse genome are methylated, the majority of which are located in repetitive elements (Solage and Cedar, 1978; Gruenbaum et al., 1981). DNA methylation of the repetitive elements may function to suppress transposon and enhance genome stability (Yoder et al., 1997).

Before the 1980s, several genes had also been found to be methylated (McGhee and Ginder, 1979) but these were considered exceptional loci because the $5-\mathrm{MeC}$ level in the unique sequences was much less than the repetitive sequences (Ehrlich et al., 1982). However, recent studies have revealed that DNA methylation is involved in the regulation of many more genes expressed in a tissue- or cell-type-specific manner, and thus plays a role in differentiation and development (Shiota, 2004; Yagi et al., 2008). The epigenetic dynamics of genes are different from those of bulk DNA. Recently there has been much more attention focused on the epigenetic regulation of genes. Currently there are $\sim 25,000$ genes annotated in the human (hg18) and mouse (mm9) genome, which comprise less than $3 \%$ of the genome (UCSC genome browser; http://genome.ucsc.edu/). Thus far, various genes with T-DMRs have been found, and the details are discussed below.

\section{DNA methylation profiles of T-DMRs in normal cells and tissues}

Genome-wide studies have shown that the mammalian genome contains numerous T-DMRs in its unique sequences. Various techniques have been utilized to obtain DNA methylation profiles of unique sequences, including: restriction land mark genomic scanning (RLGS) (Ohgane et al., 2002), genome-wide bisulfite sequencing (Eckhardt el al., 2006), and microarrays in combination with DNA methylation-sensitive restriction enzyme (Khulan et al., 2005; Yagi et al., 2008) or antibodies against 5MeC (Weber et al., 2005). All of these studies have reported a substantial amount of T-DMRs by comparing DNA methylation profiles of various somatic tissues (Ohgane et al., 2002; Shiota et al., 2002; Kremenskoy et al., 2003; Song et al., 2005; Khulan et al., 2006; Eckhardt et al., 2006; Sakamoto et al., 2008; Yagi et al., 2008), stem cells (Shiota et al., 2002; Kremenskoy et al., 2003), germ cells (Shiota et al., 2002; Oakes et al., 2007; Weber et al., 2007), primary cell types (Weber et al., 2005; Eckhardt et al., 2006; Weber et al., 2007), and cells of different sex or ages (Weber et al., 2005; Eckhardt et al., 2006). For example, RLGS with Not I, a methylation-sensitive restriction enzyme, was used to analyze the genome-wide DNA methylation status ( 1,500 loci) in mouse embryonic stem (ES) cells, embryonic germ (EG) cells, trophoblast stem (TS) cells, germ cells and several somatic tissues, which identified 247 T-DMRs where the methylation status is dependent on the cell or tissue type (Shiota et al., 2002). Taken together, each cell/tissue type has a specific methylation profile of T-DMRs, and these profiles can be used to distinguish between cell/tissue types (Fig. 1).

Based on the fact that approximately $70 \%$ of the Not I sites were located within CpG islands in the mouse genome (Fazzari and Greally, 2004), it suggested that CpG islands had T-DMRs. However, this type of T-DMRs represents a relatively small proportion (Eckhardt et al., 2006; Sakamoto et al., 2007). In addition, T-DMRs within CpG islands are generally restricted to subregions. For example, the T-DMR of the Sphk1 gene, which is conserved in the mouse, rat and human, occupies 200 base pairs (bp) at the edge of a 3.7-kilo bp CpG island, a fraction of less than $10 \%$ (Imamura et al., 2001). This type of T-DMR, which is restricted to a small $\mathrm{CpG}$ island region, has also been found in the EDNRB and POMC genes (Shiota, 2004). On the other hand, all $\mathrm{CpGs}$ in the CpG island are methylated in the Tact1/Act/7b and Ant4/S/c25a31 genes in the somatic tissues, whereas they are unmethylated in germ cells (Hisano et al., 2003; Suzuki et al., 2007). Therefore, there is a novel type of CpG island T-DMR, in which all of the CpGs are fully methylatable in normal cells. Recent genome-wide analyses have confirmed that regions with both lower CpG content as well as those having higher CpG frequencies, including $\mathrm{CpG}$ islands, were in fact methylated (Eckhardt et al., 2006; Weber et al., 2007; Sakamoto et al., 2007; Fouse et al., 2008). Collectively, there are T-DMRs associated with genes both in CpG-poor and CpG-rich sequences. In the near future, the number of T-DMRs will expand with additional studies; consequently, the DNA methylation profile in the entire genome will become more complex.

The DNA methylation profile is specific to cell and tissue type, 


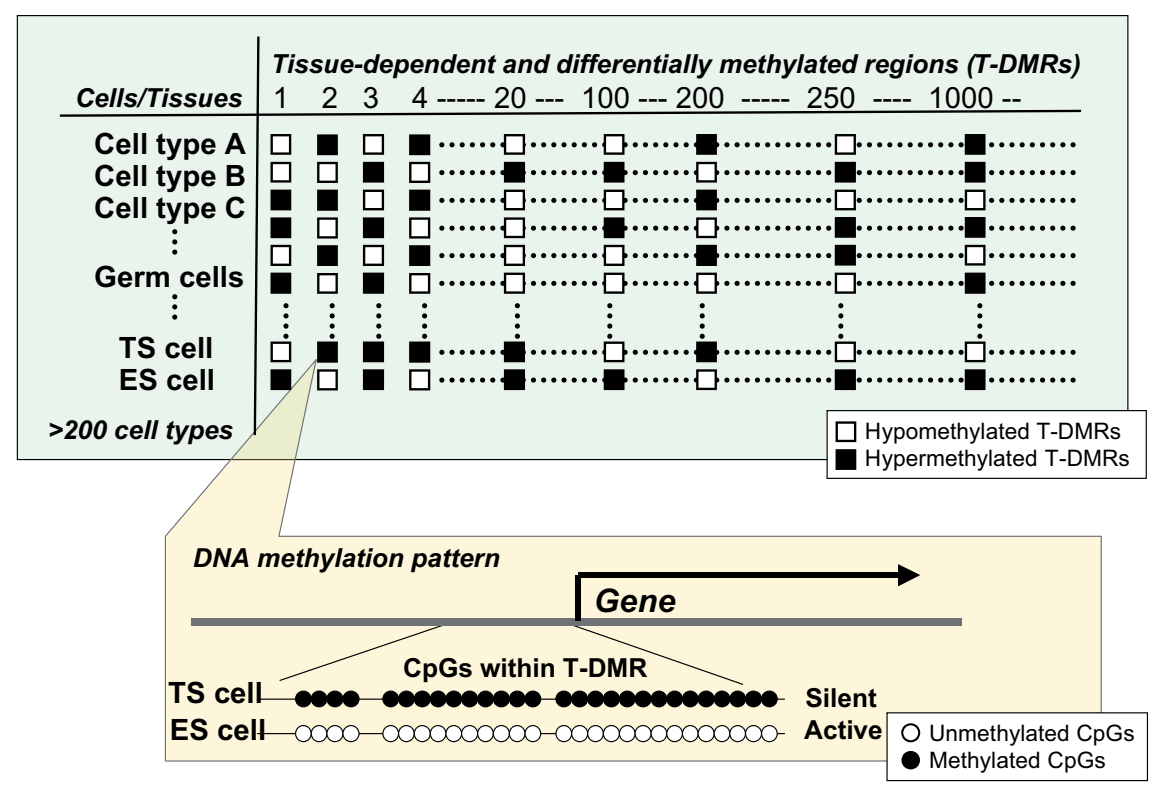

Fig. 1. Cell-type-specific DNA methylation profiles consisting of differentially methylated T-DMRs. Each cell type (ES cells and TS cells) has a unique pattern of DNA methylation at CpGs within T-DMRs (lower panel). These differential methylation status in T-DMRs constitute cell-type-specific DNA methylation profiles genome-wide (upper panel). The DNA methylation profile of a cell type can be used as a novel tool to define and characterize the cell type.

much like a fingerprint is distinct, and can be used as an identification (ID) tag for cells (Fig. 1). The DNA methylation profile also provides a novel method to evaluate the similarities of cells because it reflects the similarity in pattern of differentiation lineages (Sakamoto et al., 2007). Since DNA methylation profile is a unique ID of cells, a change in the DNA methylation profile will cause an alteration in cell properties.

\section{Epigenetic system of DNA methylation and histone modification}

\section{DNA methylation, histone modification and chromatin struc- ture}

DNA methylation status is closely associated with chromatin structure (Fig. 2). It is known that the micrococcal nucleaseresistant closed chromatin fraction predominantly contains 5$\mathrm{MeC}$ (Solage and Cedar, 1978). Histone modification also influences chromatin structure. Acetylation of lysine residues is thought to directly neutralize the positive charge of histones and contributes to a relaxation of the interaction between DNA and histones. Although this is not always the case, in vitro study showed that acetylation at $\mathrm{K} 16$ of histone $\mathrm{H} 4$ was sufficient to inhibit the formation of the 30 nanometer-like chromatin fibers (ShogrenKnaak et al., 2006). Another route mediates proteins recognizing histone modifications including chromodomain and bromodomain proteins, which bind to methylated and acetylated lysines, respectively, and affect chromatin structure as a member of the transcriptional repressor or chromatin remodeling complexes (Kouzaridez, 2007). Acetylation of histones $\mathrm{H} 3 / \mathrm{H} 4$ (H3Ac, $\mathrm{H} 4 \mathrm{Ac}$ ) and di- and trimethylation of lysine 4 of $\mathrm{H} 3$ (H3K4me2 and me3) are generally found in transcriptionally active, nucleosome-depleted, and nuclease-sensitive chromatin (Birney et al., 2007). In contrast, methylation of $\mathrm{K} 9$ and $\mathrm{K} 27$ of histone H3 (H3K9me and K27me) has usually been found in transcriptionally silent chromatin regions (Lachner et al., 2003). The profile of histone modifications in the non-repetitive regions of the genome is also unique to the tissueor cell-type (Hattori et al., 2004b; Bracken et al., 2006; Squazzo et al., 2006; Tomikawa et al., 2006; Mikkelsen et al., 2007).

\section{Epigenetic control of stemness-related genes (Oct-4 and Nanog)}

In mammalian embryogenesis, the first differentiation event that determines the lineage of the trophectoderm and inner cell mass (ICM) occurs at the blastocyst stage. ES cells established from ICM have a pluripotent ability to contribute to all embryonic lineages (Martin, 1981). TS cells established from trophectoderm have the ability to differentiate into the trophoblast lineage in vitro (Tanaka et al., 1998). The Oct-4 gene is a POU family transcription factor and has a CG-rich and TATA-less promoter. Oct- 4 is expressed in ES cells but not in TS cells (Tanaka et al., 1998), and reduction in Oct-4 gene expression induces the transdifferentiation of ES cells into TS-like cells under certain culture conditions (Niwa et al., 2000). There is a T-DMR in the promoter and enhancer region of the Oct-4 gene and the T-DMR is hypomethylated in ES cells, but hypermethylated in TS cells (Hattori et al., 2004b).

DNA hypomethylation of the T-DMR of the Oct-4 gene is associated with hyperacetylated histones in ES cells, implying that DNA methylation status is correlated with chromatin structure (Hattori et al., 2004b). Nanog is another transcription factor that is related to the stemness of preimplantation embryo and ES cells. The Nanog gene also has a T-DMR with relatively rich CpG sequences (Hattori et al., 2007). Similar to Oct-4, the Nanog TDMR is hypermethylated in TS cells and hypomethylated in ES cells. The Nanog T-DMR is also hyperacetylated in ES cells and hypoacetylated in TS cells. In the Nanog T-DMR of TS cells, lysines 9 and 27 ( $\mathrm{K} 9$ and $\mathrm{K} 27$ ) of histone $\mathrm{H} 3$ are hypermethylated. In contrast, the methylation of both K9 and K27 is low in the Oct$4 \mathrm{~T}$-DMR. Thus, these genes are regulated by an intimate relationship between DNA methylation and histone modifications in distinct combinations.

\section{Epigenetic factors involved in epigenome formation}

The mammalian genome displays a complex profile of DNA methylation and histone modifications, referred to as the epigenome. The profiles clearly show that differentiation involves massive alterations of the genome-wide epigenetic status of multiple gene loci, with changes in both DNA methylation and various histone modifications (Ohgane et al., 2002; Shiota et al., 2002; Eckhardt et al., 2006; Bracken et al., 2006; Squazzo et al., 2006; Oakes et al., 2007; Mikkelsen et al., 2007). The question is how these profiles are established in the proper cell-types at the appropriate times and how this information is inherited in subse- 
quent cellular generations. Taking recent reports into account, the interplay between DNA methylation and histone modifications is one of the mechanisms underlying the epigenetic memory (Birke et al., 2002; Fujita et al., 2003; Fuks et al., 2003a; Esteve et al., 2006; Li et al., 2006a; Vire et al., 2006; Ikegami et al., 2007). These epigenetic factors and their interplay are summarized in this section (Fig. 2).

\section{DNA methyltransferases}

In mammals, there are three functional DNA methyltransferases (Dnmts), Dnmt1, Dnmt3a and Dnmt3b. Dnmt1 and Dnmt3b knockout mice are embryonically lethal at embryonic day (E) 8.5 and 14.5-18.5, respectively, while those for Dnmt3a die at 4 weeks of age (Li et al., 1992; Okano et al., 1999), indicating the essential role of DNA methylation in mammalian development. Dnmts have been classified into two groups based on their substrate preferences. Dnmt1 preferentially adds methyl group to hemi-methylated DNA (methylated at only one of the double strands) compared with the unmethylated form in vitro (Gruenbaum et al., 1982). This implies that Dnmt1 methylates the daughter strand during replication to maintain the parental DNA methylation pattern. In fact, Dnmt1 localizes at replication foci during the $S$ phase (Leonhardt et al., 1992) and directly interacts with methyl-CpG-binding protein 2 (MeCP2), which recognizes hemi-methylated DNA (Kimura and Shiota, 2003). Hence, Dnmt1 has been called "maintenance methyltransferase" for contributing to the inheritance of DNA methylation marks over generations. The other class consists of Dnmt3a and Dnmt3b, which prefer unmethylated DNA as a substrate in vitro (Okano et al., 1998). In addition, the double knockout of Dnmt3a and Dnmt3b prevents de novo DNA methylation induced by viral infection. Hence, Dnmt3a and Dnmt3b have been termed "de novo methyltransferases" (Okano et al., 1999).

However, such classical groupings like maintenance and de novo methylation enzymes may not be adequate to understand the intracellular mechanisms, because there is direct interaction among DNMT1, 3A and 3B in vivo, as demonstrated in human cells (Kim et al., 2002). Knockout of both Dnmt3a and Dnmt3b shows progressive loss of DNA methylation at repetitive sequences with the increasing number of passages, indicating that Dnmt3a and Dnmt3b also function as "maintenance methyltransferases" (Chen et al., 2003). A number of normally methylated unique sequences cause drastic loss of DNA methylation in Dnmt3a and Dnmt3b double knockout ES cells, while only a partial reduction was achieved in Dnmt1 knockout cells (Hattori et al., 2004a). In contrast, DNA methylation levels at repetitive sequences are

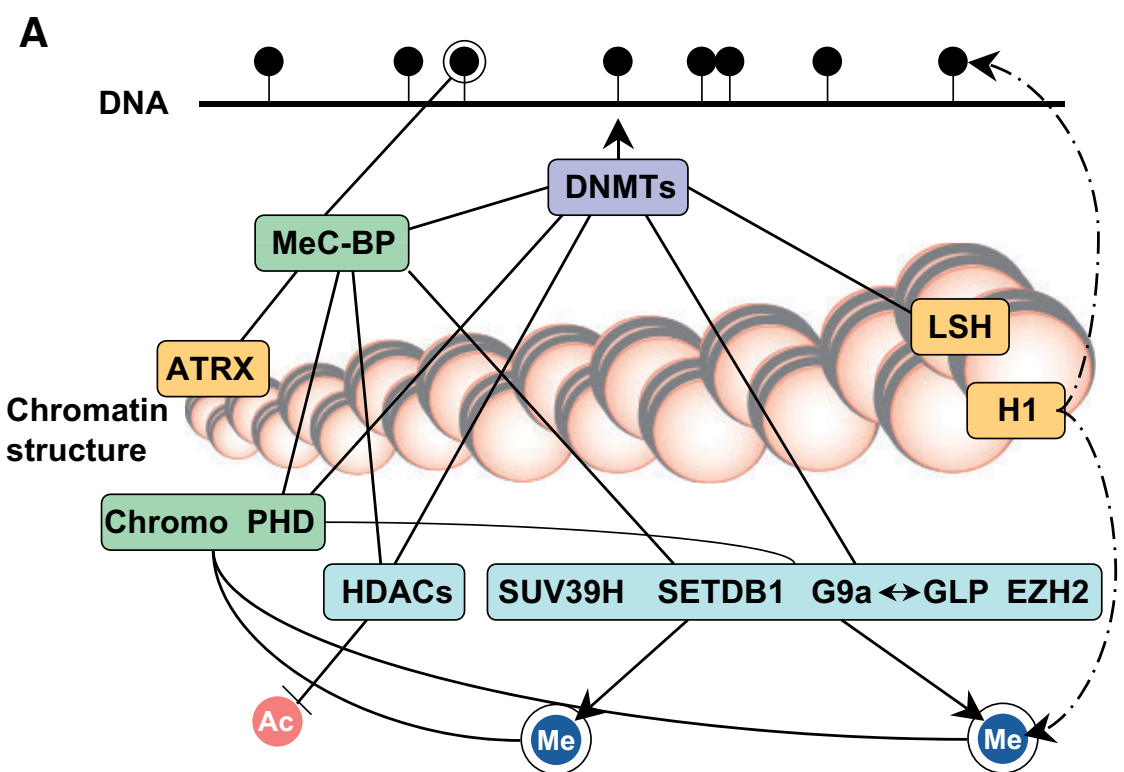

Histone H3-N-ARTKQTARK్ STGGKAPRKGLATKAARKSA

B

\section{Chromatin structure}
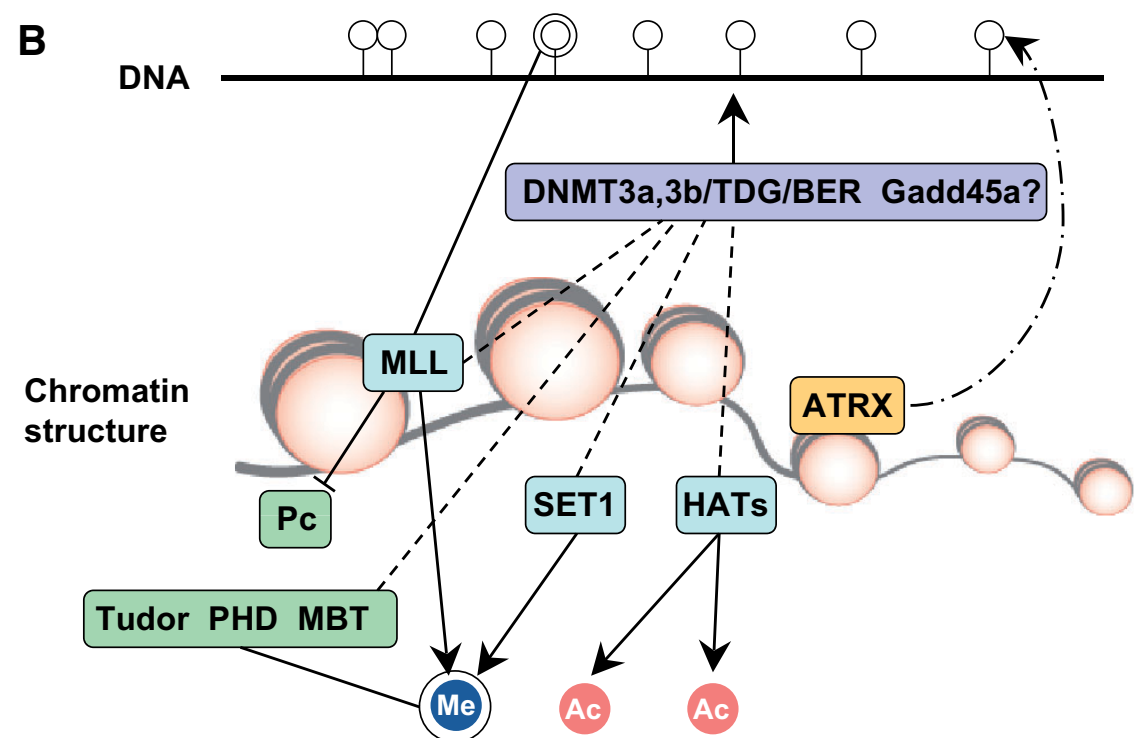

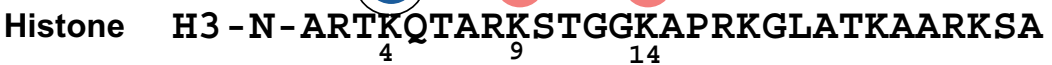

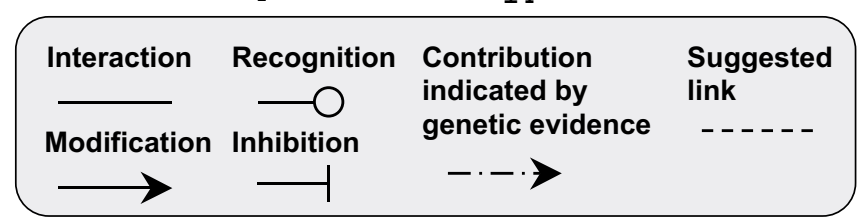

Fig. 2. Molecular link between DNA methylation, chromatin structure and histone modifications in inactive $(\mathbf{A})$ and active $(\mathbf{B})$ genomic regions. $B E R$, base excision repair proteins (e.g. AP endonuclease, DNA polymerase l); Chromo, chromodomain proteins (e.g. HP1, Pc); DNMTs, DNA methyltransferases (e.g. Dnmt1, Dnmt3s); HATs, histone acetylases (e.g. CBP/P300); HDACs, histone deacetylases (e.g. HDAC1, HDAC2); MBT, MBT domain proteins; MeC-BPs, methylCpG binding proteins (e.g. MBDs, MeCP2, UHRF1); PHD, PHD finger proteins (e.g. BPTF, SMCX); TDG, thymine DNA glycosylase; Tudor, Tudor domain proteins. 
severely affected by Dnmt1 deficiency (Li et al., 1992). Therefore, Dnmts have preferences for certain target sequence characteristics, rather than a sequential process of establishment and maintenance of DNA methylation by Dnmt3a/3b followed by Dnmt1.

A recent study showed that $D n m t 3 a / 3 b$ are able to deaminate 5-MeC in double-stranded DNA, which generates a T:G mismatch (Metivier et al., 2008). Coordinate recruitment of Dnmt3a/3b, thymine DNA glycosylase (TDG) and base excision repair (BER) proteins occurred during DNA demethylation of an estrogen receptor alpha $(E R \alpha)$ target gene, pS2 promoter, which exhibited periodic DNA methylation/demethylation during transcriptional cycling induced by estrogen (Metivier et al., 2008; Kangaspeska et al., 2008). These results suggest that Dnmt3a/3b, in cooperation with TDG and BER proteins, plays an active role in DNA demethylation. DNA demethylation has also been proposed to involve nucleotide excision repair mediated by Gadd45a (Barreto et al., 2007), although this mechanism is still controversial (Jin et al., 2008).

\section{Histone $\mathrm{H} 3$ lysine 9 methyltransferases}

Five histone $\mathrm{H} 3$ lysine 9 (H3K9) methyltransferases have been identified in mammals. These histone methyltransferases (HMTs) have a $\sim 130$ amino acid length SET (Su(var), E(z), Trithorax) domain responsible for lysine methylation activity. A $\mathrm{K} 9$ residue is modified as mono- (K9me1), di- (K9me2) or trimethylation (K9me3).

Suv39h1 and Suv39h2 are H3K9 HMTs, which predominantly localize to the DAPI-dense heterochromatin region (Aagaard et al., 1999). Suv39h1 or Suv39h2 single knockout mice display normal viability and fertility, but double mutants are born at sub-Mendelian ratios with growth retardation and male sterility (Peters et al., 2001). The Suv39h1/h2 double null exhibits loss of $\mathrm{H} 3 \mathrm{~K} 9 \mathrm{me} 3$ at pericentromeric heterochromatin and chromosome missegregation in the embryonic fibroblasts, indicating that their catalytic activities are crucial for heterochromatin organization (Peters et al., 2001). It is also known that Suv39h1, together with retinoblastoma $(\mathrm{Rb})$ protein and heterochromatin protein 1 (HP1), represses genes located in euchromatin (Nielsen et al., 2002).

G9a (officially Ehmt2) is another H3K9 HMT, which distributes in the nucleus except for pericentromeric heterochromatin (Tachibana et al., 2001; Tachibana et al., 2002). Knockout of G9a protein in ES cells exhibits drastic loss of H3K9me1 and H3K9me2 in euchromatin, indicating that G9a is a mono- and dimethyltransferase (Tachibana et al., 2002; Tachibana et al., 2005). An in vitro study has indicated that G9a can also transfer three methyl groups to a lysine residue, although this reaction is slower than dimethylation (Patnaik et al., 2004).

G9a associates with transcriptional repressors (Shi et al., 2003) and contributes to transcriptional silencing (Tachibana et al., 2002). Another report has shown that G9a also participates in transcriptional activation independent of HMT activity (Lee et al., 2006). G9a is expressed ubiquitously in somatic tissues with a high level in the testis, where G9a has a crucial role in germ cell development (Tachibana et al., 2005; Tachibana et al., 2007). G9a is also essential for early embryogenesis, because G9a knockout mice are embryonically lethal (E9.5; Tachibana et al., 2002).
GLP, (G9a-like protein; officially Ehmt1), is a H3K9 HMT structurally similar to $\mathrm{G} 9 \mathrm{a}$, forms a functional heterodimer with G9a and distributes in euchromatin. GLP deficiency is sufficient to cause drastic loss of $\mathrm{H} 3 \mathrm{~K} 9 \mathrm{me} 2$ and reactivates a known G9a target gene (Tachibana et al., 2005). GLP knockout mice die around E9.5 with almost an identical phenotype to that of G9a (Tachibana et al., 2005). However, expression pattern of GLP is slightly different from that of G9a, displaying higher and lower expression in ES cells and testis than G9a, respectively (Tachibana et al., 2005). Although only G9a but not GLP is present in primordial germ cells (PGCs) at around E7.5, these cells retain H3K9me2 in the nucleus (Seki et al., 2007). Thus, these proteins may function independently of each other in certain circumstances.

SETDB1/ESET is a euchromatin-distributed H3K9 HMT (Schultz et al., 2002). SETDB1 catalyzes H3K9me2 and H3K9me3, and mAM, a murine ATFa-associated factor AM (officially Atf7ip), facilitates SETDB1 to convert di- to trimethylation in vitro and in an artificial system in vivo (Wang et al., 2003). SETDB1 participates in gene silencing with transcriptional repressors/corepressors including KAP-1, mAM, mSin3A/B (Schultz et al., 2002; Wang et al., 2003; Yang et al., 2003). SETDB1 deficiency exhibits a more severe phenotype in the mouse than those of Suv39h, G9a and GLP HMTs, as it results in peri-implantation lethality between $\mathrm{E} 3.5$ and 5.5, and knockout ES cells cannot be derived (Dodge et al., 2004).

\section{Histone H3 lysine 27 methyltransferases}

Ezh2 is a SET domain protein catalyzing methylation of histone $\mathrm{H} 3$ at lysine 27 (H3K27) (Cao et al., 2002). Ezh2, together with Eed, Suz12 and Rbbp4/7 forms Polycomb repressive complex 2 (PRC2), which is liked to $X$ inactivation and cooperates with $\mathrm{PRC} 1$ to act as a transcriptional repressor of multiple developmental genes including homeobox genes (Schuettengruber et al., 2007). Either Eed or Suz12 deficiency causes a sharp reduction of the Ezh2 and H3K27 methylation levels, indicating that Suz12 and Eed have a crucial role in the methyltransferase activity of Ezh2 (Pasini et al., 2004; Montgomery et al., 2005). Interestingly, Eed knockout exhibits loss of H3K27me1, K27me2 and K27me3, whereas that of Suz12 results in reduction of only K27me2 and K27me3, suggesting that Eed may contribute to the substrate-specificity of Ezh2 (Pasini et al., 2004; Montgomery et al., 2005).

Ezh2 knockout mice exhibit peri-implantation lethality ( E7.5), and mutant ES cells cannot be derived from blastocysts, indicating that Ezh2 plays a crucial role in early development such as gastrulation (O'Carroll et al., 2001). Likewise, both Suz12 knockout and Eed knockout mice display embryonic lethality around E7.5-8.5 (Faust et al., 1995; Pasini et al., 2004). Thus far, genome-wide studies have revealed that there are many PRC2 target genes which overlap with H3K27me3 in the mammalian genome in stem and somatic cells (Boyer et al., 2006; Bracken et al., 2006; Lee et al., 2006; Squazzo et al., 2006).

G9a and GLP also exhibit methyltransferase activity for $\mathrm{H} 3 \mathrm{~K} 27$, although this is weaker than that for $\mathrm{H} 3 \mathrm{~K} 9$ in vitro (Tachibana et al., 2001; Tachibana et al., 2005). G9a deficiency does not alter the global level of H3-K27 methylation in ES cells (Peters et al., 2003). Rougeulle et al. (2004) did not detect reduction of H3K27 methylation at the Xist gene on the male X- 
chromosome in G9a knockout ES cells. However, G9a target regions, in which G9a deficiency causes DNA hypomethylation, display a decreased H3K9me2 as well as H3K27me2 levels in G9a knockout ES cells (Ikegami et al., 2007). This finding suggests that G9a also catalyzes H3K27me2 in vivo.

\section{DNA methylation directs histone H3K9 methylation}

The Arabidopsis mutant null for MET1, a DNMT1-like CpG methyltransferase, displays drastic loss of H3K9 methylation in heterochromatic regions including transposons (Tariq et al., 2003). In the human cancer cell line, deficiency of DNMT1 exhibits global reduction of $\mathrm{H} 3 \mathrm{~K} 9 \mathrm{me} 2$ and $\mathrm{H} 3 \mathrm{~K} 9 \mathrm{me} 3$, and transfection of murine Dnmt1 rescues this phenotype (Espada et al., 2004). Interestingly, this DNMT1 knockout cell line displays increased sensitivity to micrococcal nuclease digestion, indicating the role of DNMT1 in chromatin organization. Similarly, knockdown of DNMT1 by siRNA causes reduction in H3K9me1, K9me2 and K9me3 levels at intergenic spacer elements of ribosomal DNA (rDNA) (Esteve et al., 2006). However, Dnmt1/Dnmt3a/Dnmt3b triple knockout ES cells, which exhibit complete loss of DNA methylation at several repetitive sequences and imprinting genes, do not exhibit reduction of the global levels of $\mathrm{H} 3 \mathrm{~K} 9 \mathrm{me} 2$ and $\mathrm{H} 3 \mathrm{~K} 9 \mathrm{me} 3$ nor alter localization pattern of $\mathrm{H} 3 \mathrm{~K} 9 \mathrm{me} 3$ and $\mathrm{HP} 1 \beta$ (Tsumura et al., 2006).

\section{Histone H3K9/K27 methylation directs DNA methylation}

The Neurospora crassa mutant of the gene encoding Dim-5, a H3K9 HMT, exhibits a decrease in DNA methylation levels in specific regions including rDNA genes and transposons (Tamaru and Selker, 2001). In Arabidopsis, a mutation of the H3K9 methyltransferase KRYPTONITE gene results in a reduction of asymmetric CpNpG methylation levels (where $\mathrm{N}$ is $\mathrm{A}, \mathrm{C}, \mathrm{G}$, or T) (Jackson et al., 2002). In mouse ES cells, double null of Suv39h1 and Suv39h2 causes a reduction of DNA methylation levels in major satellite repeats of the pericentromeric region (Lehnertz et al., 2003). ES cells lacking G9a exhibit a reduction of DNA methylation together with H3K9 methylation at the known imprinting gene Snrpn (Xin et al., 2003). RNA interference of EZH2 reduces H3K27 methylation levels and DNA methylation levels at known EZH2 target genes (Vire et al., 2006).

SETDB1 may also affect DNA methylation because SETDB1 interacts with MBD1 and DNMT3A (Sarraf et al., 2004; Li et al., 2006a) (Discussed below). However, knockout of SETDB1 in blastocysts did not change the DNA methylation levels at the interspersed repetitive elements (Dodge et al., 2004).

Genome-wide DNA methylation analysis of ES cells revealed that G9a deficiency causes reduction of DNA methylation levels at $1.6 \%$ (32 loci) of the total of $\sim 2,000$ genic loci analyzed (Ikegami et al., 2007). At these regions, G9a knockout ES cells exhibit reduced levels of H3K9me2 and/or H3K27me2, and the G9a-transgene rescues the DNA methylation status in G9a knockout cells. Importantly, however, DNA methylation levels remained intact at a majority of the genic loci in the G9a knockout ES cells. Therefore, G9a participates in DNA methylation in a locus-specific manner (Ikegami et al., 2007).

Collectively, these reports show that H3K9 and K27 methylation can direct DNA methylation of gene regions, providing clues for how local DNA methylation or demethylation occurs when Dnmts, the global regulators, establish the genome-wide DNA methylation profile.

\section{Interaction between H3K9/27 HMTs and Dnmts}

Co-expression study revealed that human SUV39H1 binds to murine Dnmt1 and Dnmt3a (Fuks et al., 2003a). In a breast cancer cell line, sequential ChIP analysis with antibodies against DNMT3A and SETDB1 revealed that SETDB1 binds to DNMT3A on chromatin ( $\mathrm{Li}$ et al., 2006a). Direct interaction between H3K27 methyltransferase EZH2 and DNMTs (DNMT1, 3A and 3B) was also reported (Vire et al., 2006), supporting the notion that H3K27 methylation links to DNA methylation. Furthermore, DNMTs associate with EZH2-target genes in the presence of $\mathrm{EZH} 2$ (Vire et al., 2006).

G9a also interacts with DNMT1 and co-localizes specifically in the S-phase of synchronized human cells (Esteve et al., 2006). In the report, both G9a and DNMT1 localized at replication sites, as judged by strong BrdU incorporation. Therefore, G9a and DNMT1 may cooperatively maintain the H3K9 methylation and the DNA methylation pattern at replication foci.

The molecular interaction between the proteins directly involved in DNA methylation and H3K9/K27 methylation suggests that both modifications could be the basis for recruiting the other.

\section{Proteins recognizing DNA methylation}

The human genome encodes 12 proteins containing the methyl-CpG-binding domain (MBD), which is the protein motif responsible for binding to methylated CpG dinucleotide (http:// www.ebi.ac.uk/interpro). Among them, MeCP2, MBD1, MBD2, and MBD4 have been shown to specifically recognize methylCpG (Klose and Bird, 2006). In contrast to animals deficient for Dnmts and HMTs, mutant of each of these $4 \mathrm{MBD}$ proteins survives to adulthood (Fatemi and Wade, 2006). However, mutation of the Xlinked MeCP2 gene causes the neurological disease Rett syndrome almost exclusively in females, which results in developmental arrest between 6 and 18 months of age in human (Amir et al., 1999).

Kaiso, (officially Zbtb33), Zbtb4 and Zbtb38 use an ancestral three-zinc-finger motif to bind to methylCpG, but are differentially expressed in mouse tissues, suggesting nonoverlapping functions or targets (Prokhortchouk et al., 2001; Filion et al., 2006). UHRF1 (ubbiqutin-like, containing PㅂD and $\underline{R} I N G$ finger domains 1), a binding partner of Dnmt1, preferentially binds to hemimethylated DNA via its SRA ( $\underline{S E T}$ and $\underline{R}$ ING associated) domain (Bostick et al., 2007). Knockout of Uhrf1 gene leads to mislocalization of Dnmt1 in $S$ phase and reduction of DNA methylation levels, suggesting a role of UHRF1 in maintaining DNA methylation patterns (Bostick et al., 2007; Sharif et al., 2007).

\section{Proteins recognizing histone methylation}

Chromodomain recognizes methylation of lysines 9 and 27, which reside within a highly related sequence motif Ala-Arg-LysSer (ARKS). HP1 proteins (HP1 $\alpha, \beta$ and $\gamma$ ) bind to methylated H3K9 via their chromodomains (Lachner et al., 2001). HP1 also directly binds to SUV39H1 (Aagaard et al., 1999) and G9a (Sampath et al., 2007). Another chromodomain protein, Polycomb (Pc), a member of PRC1, binds to methylated H3K27 (Fischle et 
al., 2003). Biochemical assay and crystallography demonstrated that Drosophila HP1 and Pc specifically interact with $\mathrm{H} 3 \mathrm{~K} 9 \mathrm{me} 3$ and H3K27me3, respectively (Fischle et al., 2003). However, in mice, none of the five murine Polycomb homologs ( $\mathrm{Cbx} 2, \mathrm{Cbx} 4$, Cbx6, Cbx7, and $\mathrm{Cbx8}$ ) has exclusive preference for K27me3 (Bernstein et al., 2006). Instead, Cbx2 and $\mathrm{Cbx} 7$ display strong affinity for both $\mathrm{K} 9 \mathrm{me} 3$ and $\mathrm{K} 27 \mathrm{me} 3$, and $\mathrm{Cbx} 4$ inversely prefers K9me3 similar to HP1 (Bernstein et al., 2006). HP1 and Cbx4 might have a role in the discrimination of $\mathrm{H} 3 \mathrm{~K} 9$ from $\mathrm{H} 3 \mathrm{~K} 27$ methylation in mammals.

Tudor domains that are structurally related to chromodomain, bind to methyllysines. JMJD2A recognizes H3K4/H3K20me3 through the domain, and also demethylates $\mathrm{H} 3 \mathrm{~K} 9 / \mathrm{H} 3 \mathrm{~K} 36 \mathrm{me} 3$ via jumonji C (jmjC) domain (Huang et al., 2006; Klose et al., 2006). Proteins having a MBT (malignant brain tumor) domain, which is also chromodomain-related, have a broader spectrum of target lysines including H3K4, H3K9, H3K27, H3K36, H4K20 and K26 of histone $\mathrm{H} 1$ isotype b (Trojer and Reinberg, 2008). Another type, $\mathrm{PHD}$ (plant homeodomain) finger domain is structurally nonrelated to chromodomain. Various PHD finger proteins involving transcriptional activation, repression, and recombination have been reported to recognize H3K4me3 (Kouzarides et al., 2007). More recently, SMCX (officially JARID1C), a jmjC domain-containing $\mathrm{H} 3 \mathrm{~K} 4 \mathrm{me} 3$ demethylase, is reported to bind $\mathrm{H} 3 \mathrm{~K} 9 \mathrm{me} 3$ via PHD domain (Iwase et al., 2007).

\section{Proteins connecting DNA methylation and histone methyla- tion}

The MBD proteins have a role in connecting DNA methylation to histone methylation. MBD1 directly interacts with Suv39h1 in vitro and colocalizes with Suv39h1 in vivo in a MBD-dependent manner (Fujita et al., 2003). MBD1 also interacts with HP1 (Fujita et al., 2003). Similarly, MeCP2 has been shown to associate with H3K9 methyltransferase activity, although the exact partner(s) have not been identified (Fuks et al., 2003b). Therefore, MBD proteins play a role in recruiting $\mathrm{H} 3 \mathrm{~K} 9$ methylation to the site of DNA methylation, and/or HMT recruits MBD proteins to facilitate their binding to methylated CpG. Recently, the in vivo interaction of MBD1 with SETDB1 has been demonstrated (Sarraf et al., 2004). During replication, chromatin assembly factor-1 (CAF-1, officially CHAF1), a histone chaperone complex interacting with PCNA, joins to form the S-phase-specific MBD1/SETDB1/CAF-1 complex (Sarraf et al., 2004). MBD1 may participate in maintaining the H3K9 methylation pattern along with that of DNA methylation at replication foci. Finally, since SETDB1 itself has a MBD motif, the internal MBD may direct $\mathrm{H} 3 \mathrm{~K} 9$ methylation at $\mathrm{CpG}$ methylated genomic regions.

HP1 proteins are linked to the DNA methylation system. HP1 proteins interact with DNMT1, DNMT3A and DNMT3B in vitro or on co-expression analysis (Fuks et al., 2003a; Smallwood et al., 2007). In vivo, HP1 $\alpha$ interacts with Dnmt3b but does not interact or very weakly with Dnmt1 and Dnmt3a (Lehnertz et al., 2003). Therefore, HP1 may recruit Dnmts where H3K9 is methylated. HP1 proteins seem to localize differentially in the nucleus during the cell cycle. For example, HP1 $\beta$ localizes most preferentially among the three HP1s to the centromere during the interphase, whereas only HP1 $\alpha$ localizes to the centromere during the metaphase in human cells (Hayakawa et al., 2003). Thus, HP1 may affect localization of Dnmt during the cell cycle. HP1 proteins also directly interact with MeCP2 in an overexpression experiment (Agarwal et al., 2007). These results suggest that H3K9 methylation recruits DNA methylation via HP1 proteins, and that HP1 localization is influenced by DNA methylation pattern via MBD proteins.

\section{DNA methylation and other histone modifications}

In mammals, there are at least ten known or predicted H3K4 methyltransferases, which are generally categorized into the MLL (mixed lineage leukemia) family, Set1 family and others (Ruthenburg et al., 2007). MLL, a H3K4 HMT, is a member of the trithorax group, which in general functions antagonistically against polycomb group proteins. At a trithorax/polycomb target gene, Hox c8, MLL deficiency causes reductions of the expression and H3K4 methylation levels together with an increased DNA methylation level in a mouse embryonic fibroblast cells (Milne et al., 2002). Similarly, mice lacking the SET domain of MLL display decreased H3K4me1 and increased DNA methylation levels in the Hox d4 gene (Terranova et al., 2006). Interestingly, this mutant does not exhibit a global change of H3K4me1 and DNA methylation, indicating that $\mathrm{H} 3 \mathrm{~K} 4$ methylation affects DNA methylation in a locus-specific manner. This notion is supported by the recent genome-wide study demonstrating that there are substantial amount of genes marked by H3K4me3 with either DNA hyperor hypomethylation at promoters (Fouse et al., 2008). It is noteworthy that MLL shares homology with Dnmt1 in the methyltransferase domain, which selectively binds to unmethylated $\mathrm{CpG}$ sequences in vitro (Birke et al., 2002). However, forced expression of exogenous MLL in MLL knockout cells does not reduce DNA methylation levels (Milne et al., 2002). Therefore H3K4 methylation may protect certain loci from DNA methylation.

Histone deacetylase 1 (HDAC1) associates with MeCP2 in a corepressor complex, providing a model in which the loci with hypermethylated $\mathrm{CpGs}$ undergo histone deacetylation by this complex (Nan et al., 1998). In addition, HDAC1 and HDAC2 directly interact with DNMT1 (Fuks et al., 2003b; Robertson et al., 2000; Rountree et al., 2000). Treatment of Neurospora crassa with Trichostatin A (TSA), an inhibitor of histone deacetylase, causes reduction of DNA methylation in several genes, whereas it does not affect the global DNA methylation in repetitive sequences (Selker, 1998). In the human colorectal carcinoma cell line, TSA treatment does not affect the DNA methylation status of the $\mathrm{CpG}$ islands of two silent genes that were heavily methylated (Cameron et al., 1999). TSA treatment reduces mRNA and protein levels of DNMT3B in human endometrial cells and those of DNMT1 in Jurkat T cells, respectively (Xiong et al., 2005; Januchowski et al., 2007). Therefore, there seems to be in each a dependency between the histone acetylation and DNA methylation.

\section{Molecular link among DNA methylation, chromatin or- ganization and non-coding RNAs}

\section{Chromatin remodeling factors, linker histone and DNA me- thylation}

Other than histone modifications, several proteins associated with chromatin have been reported to be linked with DNA methylation (Fig. 2). One is Lsh (lymphoid specific helicase, officially Hells), a member of the SNF2 ATPase/helicase family, which is 
involved in chromatin remodeling. Tissues from Lsh knockout mice exhibit DNA hypomethylation at satellite and interspersed repetitive sequences as well as unique sequences including the tissuespecific genes, beta-Globin and Pgk-2 (Dennis et al., 2001). Lsh interacts with Dnmt3a and Dnmt3b, but not with Dnmt1 (Zhu et al., 2006). DNA demethylation at repetitive sequences appears more severe in Lsh knockout cells than that in Dnmt3a/Dnmt3b double knockout cells, suggesting that Dnmt1 activity is also influenced by Lsh (Dennis et al., 2001). Dnmts may require the chromatin remodeling function of Lsh for their catalytic activities.

ATRX ( $\underline{X}$-linked alpha thalassemia/mental retardation) is another member of the SNF2 family of ATPase/helicase proteins. Patients having mutation in the ATRX gene display DNA hypomethylation at rDNA and hypermethylation at a satellite repeat (Gibbons et al., 2000). The ATRX protein interacts with MeCP2 in co-transfected cells, and both proteins colocalize at the DAPI-dense heterochromatin domain in the adult brain of the mouse (Nan et al., 2007). In MeCP2-null brain, ATRX delocalizes from heterochromatin (Nan et al., 2007). These reports suggest that DNA methylation and ATRX chromatin remodeling affect each other.

Several reports have demonstrated that linker histone $\mathrm{H} 1$ preferentially binds to methylated DNA (Levine et al., 1993; McArthur and Thomas, 1996), whereas others have reported that DNA methylation does not affect $\mathrm{H} 1$ binding (Campoy et al., 1995; Nightingale and Wolffe, 1995). Recent fluorescence recovery after photobleaching (FRAP) analysis showed that $\mathrm{Dnmt3a/Dnmt3b}$ double knockout causes a delay of the recovery kinetics of linker histones, $\mathrm{H} 1$ and $\mathrm{H} 5$, in ES cells (Gilbert et al., 2007). DNA methylation seems to facilitate linker histone assembly in vivo.

Conversely, histone $\mathrm{H} 1$ influences DNA methylation status as well. Knockout of three $\mathrm{H} 1$ isotypes $(\mathrm{H} 1 \mathrm{c}, \mathrm{H} 1 \mathrm{~d}$, and $\mathrm{H} 1 \mathrm{e})$ exhibiting global changing of chromatin structure induces DNA demethylation at specific genes but not satellite or interspersed repetitive sequences (Fan et al., 2005). This mutant also displays global reduction of $\mathrm{H} 3 \mathrm{~K} 12$ acetylation and H3K27me3.

Collectively, proteins associated with chromatin affect establishment of DNA methylation pattern directly or indirectly via histone modifications, and inversely, DNA methylation influences the distribution and/or function of these proteins.

\section{Higher-order chromatin and DNA methylation}

DNA methylation has a role in the organization of higherorder chromatin structure. Dnmt3b-deficient murine embryonic fibroblast cells exhibit reduced DNA methylation levels at endogenous repetitive sequences and a higher rate of polyploidy and aneuploidy in culture (Dodge et al., 2005). Lymphoblastoid cell lines established from patients with immunodeficiency syndrome, centromeric region instability, and facial anomalies (ICF syndrome), which is caused by mutations in the DNMT3B gene, also display chromosomal abnormalities including metaphase chromosome decondensation, anaphase and/or interphase chromatin bridging, and abnormal chromatin looping (Gisselsson et al., 2005). Dnmt3a/Dnmt3b double null ES cells exhibit increased clustering of pericentromeric heterochromatin into a few large chromocenters (Gilbert et al., 2007). Therefore, DNA methylation contributes to chromosome dynamics. However, triple knockout of Dnmt1, Dnmt3a and Dnmt3b does not affect the chromosome number in murine ES cells (Tsumura et al., 2006).

\section{Non-coding RNA in the directing of DNA methylation and histone modification}

Genetic analyses in plants have revealed that non-coding RNA (ncRNA) is involved in DNA methylation, and this system is known as RNA-dependent DNA methylation (Zaratiegui et al., 2007). In human cells, transfection of 21-nucleotide (nt) RNA homologous to the promoter sequence of EF1A gene increased the DNA methylation level in the promoter region (Morris et al., 2004). In the RASSF1A gene, short hairpin RNAs (shRNA) containing 21-nt sequences complementary to promoter $\mathrm{CpG}$ island induced a very low level of or no detectable DNA methylation in the target region depending on the analysis methods (Castanotto et al., 2005). More recently, knockout of the Piwi proteins, MIWI2 and MILI, which bind to 26-31-nt piRNAs (Piwi-interacting small RNAs), has been reported to decrease DNA methylation levels of transposons in murine male germ cells (Aravin et al., 2007; Kuramochi-Miyagawa et al., 2008). These findings suggest an involvement of piRNA in the DNA methylation system.

In contrast, there are reports that ncRNA did not induce DNA methylation. The 19-nt sequence overlapping the transcription start site of the human $P G R$ gene reduced the mRNA level but did not induce DNA methylation around the target sites in a human cancer cell line (Janowski et al., 2005). Similarly, 21nt doublestranded RNAs (dsRNAs), which are homologous to the CpG island of the $C D H 1$ promoter, induced $\mathrm{H} 3 \mathrm{~K} 9$ me2 dimethylation and transcriptional silencing but not DNA methylation (Ting et al., 2005). Furthermore, the RNA-mediated transcriptional repression was accomplished in cells genetically lacking DNMT1 and DNMT3B (Ting et al., 2005). Collectively, RNA-dependent induction of DNA methylation still remains to be addressed in mammals.

As noted above, shRNA-transfected cells exhibit increased H3K9me2 levels at the CHD1 promoter (Ting et al., 2005). Similarly, 21 nt RNA homologous to the integrated CCR5 gene promoter induces H3K9me2 at the promoter (Kim et al., 2006). H3K27me3 and EZH2 levels increase at the RASSF1A gene promoter in HeLa cells stably expressing shRNA targeting the promoter (Kim et al., 2006). Interaction between long ncRNA and G9a or EZH2 has been recently shown (Nagano et al., 2008; Pandey et al., 2008). These reports suggest that ncRNA plays a role in the H3K9 and K27 methylation system in mammals.

In contrast to the findings above, ncRNAs have also been suggested to trigger demethylation of DNA and H3K9 in mammalian systems. Human cancer cell lines transfected with 21-nt dsRNA targeting the E-cadherin promoter induces transcription and decreases the H3K9me2 and H3K9me3 levels in the target region with the CpG island (Li et al., 2006b). Imamura et al., (2004) reported that transfection of 0.2-1.0 kbp antisense ncRNAs corresponding to the $\mathrm{CpG}$ island of the Sphk1 gene induces demethylation of $\mathrm{CpG}$ sites and methylation of $\mathrm{CC}(\mathrm{A} / \mathrm{T}) \mathrm{GG}$ sites at the T-DMR in the $\mathrm{CpG}$ island. Importantly, these antisense RNAs are in fact transcribed from the $\mathrm{CpG}$ island in rat tissues (Imamura et al., 2004).

\section{Conclusion}

The cell- and tissue-specific expression of genes, including 
transcription factors, have traditionally been explained through the regulation by the transcription factors active in the cell/tissue type. However, the regulation by transcription factors is generally temporally constrained and rapidly changeable in response to environmental and extra-cellular stimuli. It is becoming clear that various genes are controlled by epigenetic systems of DNA methylation and histone modifications. DNA methylation profiles are, in a certain sense, the epigenetic memory that is indispensable for cells and tissues to maintain their unique features.

Analysis of DNA methylation profiles provides us a survey of the epigenetic status of the entire genome, because various histone modifications and chromatin remodeling generally reflect the genome-wide DNA methylation status (Fig. 2). We are now in the era of the epigenome, the "Total information of epigenetic marks on the genome". The epigenome connects the genome (DNA sequence) and transcriptome by introducing another layer of genetic control: a stable memory of the genetic activity for numerous genes, which is heritable to the next generation. The epigenome will provide new insight into mammalian development and the differentiation of cells. In addition, epigenetic analysis provides a new paradigm for understanding the normal and abnormal status of cells. Direct/indirect interactions among Dnmts, histone modification enzymes, histone subtypes, chromatin remodeling factors and ncRNAs underlie the establishment of the cell-type specific epigenome.

\section{Acknowledgment}

We greatly appreciate Paul G. Giresi for invaluable suggestions, critical review and helpful proofreading of the manuscript.

\section{References}

AAGAARD, L., LAIBLE, G., SELENKO, P., SCHMID, M., DORN, R., SCHOTTA, G., KUHFITTIG, S., WOLF, A., LEBERSORGER, A., SINGH, P.B. et al. (1999). Functional mammalian homologues of the Drosophila PEV-modifier Su(var)39 encode centromere-associated proteins which complex with the heterochromatin component M31. EMBO J 18: 1923-1938.

AGARWAL, N., HARDT, T., BRERO, A., NOWAK, D., ROTHBAUER, U., BECKER, A., LEONHARDT, H. and CARDOSO, M.C. (2007). MeCP2 interacts with HP1 and modulates its heterochromatin association during myogenic differentiation. Nucleic Acids Res 35: 5402-5408.

AMIR, R.E., VAN DEN VEYVER, I.B., WAN, M., TRAN, C.Q., FRANCKE, U. and ZOGHBI, H.Y. (1999). Rett syndrome is caused by mutations in X-linked MECP2, encoding methyl-CpG-binding protein 2. Nat Genet 23: 185-188.

ARAVIN, A.A., SACHIDANANDAM, R., GIRARD, A., FEJES-TOTH, K. and HANNON, G.J. (2007). Developmentally regulated piRNA clusters implicate MILI in transposon control. Science 316: 744-7.

BARRETO, G., SCHAFER, A., MARHOLD, J., STACH, D., SWAMINATHAN, S.K., HANDA, V., DODERLEIN, G., MALTRY, N., WU, W., LYKO, F. et al. (2007). Gadd45a promotes epigenetic gene activation by repair-mediated DNA demethylation. Nature 445: 671-675.

BERNSTEIN, E., DUNCAN, E.M., MASUI, O., GIL, J., HEARD, E. and ALLIS, C.D. (2006). Mouse polycomb proteins bind differentially to methylated histone $\mathrm{H} 3$ and RNA and are enriched in facultative heterochromatin. Mol Cell Biol 26: 2560-2569.

BIRD, A. (2002). DNA methylation patterns and epigenetic memory. Genes Dev 16: 6-21.

BIRKE, M., SCHREINER, S., GARCIA-CUELLAR, M.P., MAHR, K., TITGEMEYER, F. and SLANY, R.K. (2002). The MT domain of the proto-oncoprotein MLL binds to CpG-containing DNA and discriminates against methylation. Nucleic Acids Res 30: 958-965.

BIRNEY, E.STAMATOYANNOPOULOS, J.A.DUTTA, A.GUIGO, R.GINGERAS, T.R.MARGULIES, E.H.WENG, Z.SNYDER, M.DERMITZAKIS, E.T.THURMAN,
R.E. et al. (2007). Identification and analysis of functional elements in $1 \%$ of the human genome by the ENCODE pilot project. Nature 447: 799-816.

BOSTICK, M., KIM, J.K., ESTEVE, P.O., CLARK, A., PRADHAN, S. and JACOBSEN, S.E. (2007). UHRF1 plays a role in maintaining DNA methylation in mammalian cells. Science 317: 1760-1764.

BOYER, L.A., PLATH, K., ZEITLINGER, J., BRAMBRINK, T., MEDEIROS, L.A., LEE, T.I., LEVINE, S.S., WERNIG, M., TAJONAR, A., RAY, M.K. et al. (2006). Polycomb complexes repress developmental regulators in murine embryonic stem cells. Nature 441: 349-353.

BRACKEN, A.P., DIETRICH, N., PASINI, D., HANSEN, K.H. and HELIN, K. (2006) Genome-wide mapping of Polycomb target genes unravels their roles in cell fate transitions. Genes Dev 20: 1123-1136.

CAMERON, E.E., BACHMAN, K.E., MYOHANEN, S., HERMAN, J.G. and BAYLIN, S.B. (1999). Synergy of demethylation and histone deacetylase inhibition in the re-expression of genes silenced in cancer. Nat Genet 21: 103-107.

CAMPOY, F.J., MEEHAN, R.R., MCKAY, S., NIXON, J. and BIRD, A. (1995). Binding of histone $\mathrm{H} 1$ to DNA is indifferent to methylation at $\mathrm{CpG}$ sequences. $J$ Biol Chem 270: 26473-26481.

CAO, R., WANG, L., WANG, H., XIA, L., ERDJUMENT-BROMAGE, H., TEMPST, P., JONES, R.S. and ZHANG, Y. (2002). Role of histone H3 lysine 27 methylation in Polycomb-group silencing. Science 298: 1039-1043.

CASTANOTTO, D., TOMMASI, S., LI, M., LI, H., YANOW, S., PFEIFER, G.P. and ROSSI, J.J. (2005). Short hairpin RNA-directed cytosine (CpG) methylation of the RASSF1A gene promoter in HeLa cells. Mol Ther 12: 179-183.

CHEN, T., UEDA, Y., DODGE, J.E., WANG, Z. and LI, E. (2003). Establishment and maintenance of genomic methylation patterns in mouse embryonic stem cells by Dnmt3a and Dnmt3b. Mol Cell Biol 23: 5594-5605.

DENNIS, K., FAN, T., GEIMAN, T., YAN, Q. and MUEGGE, K. (2001). Lsh, a member of the SNF2 family, is required for genome-wide methylation. Genes Dev 15: 2940-2944.

DODGE, J.E., KANG, Y.K., BEPPU, H., LEI, H. and LI, E. (2004). Histone H3-K9 methyltransferase ESET is essential for early development. Mol Cell Biol 24: 2478-2486.

DODGE, J.E., OKANO, M., DICK, F., TSUJIMOTO, N., CHEN, T., WANG, S., UEDA, Y., DYSON, N. and LI, E. (2005). Inactivation of Dnmt3b in mouse embryonic fibroblasts results in DNA hypomethylation, chromosomal instability, and spontaneous immortalization. J Biol Chem 280: 17986-17991.

ECKHARDT, F., LEWIN, J., CORTESE, R., RAKYAN, V.K., ATTWOOD, J., BURGER, M., BURTON, J., COX, T.V., DAVIES, R., DOWN, T.A. et al. (2006). DNA methylation profiling of human chromosomes 6, 20 and 22. Nat Genet 38 1378-1385.

EHRLICH, M., GAMA-SOSA, M.A., HUANG, L.H., MIDGETT, R.M., KUO, K.C., MCCUNE, R.A. and GEHRKE, C. (1982). Amount and distribution of 5methylcytosine in human DNA from different types of tissues of cells. Nucleic Acids Res 10: 2709-2721.

ESPADA, J., BALLESTAR, E., FRAGA, M.F., VILLAR-GAREA, A., JUARRANZ, A., STOCKERT, J.C., ROBERTSON, K.D., FUKS, F. and ESTELLER, M. (2004). Human DNA methyltransferase 1 is required for maintenance of the histone $\mathrm{H} 3$ modification pattern. J Biol Chem 279: 37175-37184.

ESTEVE, P.O., CHIN, H.G., SMALLWOOD, A., FEEHERY, G.R., GANGISETTY, O., KARPF, A.R., CAREY, M.F. and PRADHAN, S. (2006). Direct interaction between DNMT1 and G9a coordinates DNA and histone methylation during replication. Genes Dev 20: 3089-3103.

FAN, Y., NIKITINA, T., ZHAO, J., FLEURY, T.J., BHATTACHARYYA, R., BOUHASSIRA, E.E., STEIN, A., WOODCOCK, C.L. and SKOULTCHI, A.I. (2005). Histone $\mathrm{H} 1$ depletion in mammals alters global chromatin structure but causes specific changes in gene regulation. Cell 123: 1199-1212.

FATEMI, M. and WADE, P.A. (2006). MBD family proteins: reading the epigenetic code. J Cell Sci 119: 3033-3037.

FAUST, C., SCHUMACHER, A., HOLDENER, B. and MAGNUSON, T. (1995). The eed mutation disrupts anterior mesoderm production in mice. Development 121 : 273-285.

FAZZARI, M.J. and GREALLY, J.M. (2004). Epigenomics: beyond CpG islands. Nat Rev Genet 5: 446-455.

FILION, G.J., ZHENILO, S., SALOZHIN, S., YAMADA, D., PROKHORTCHOUK, E. and DEFOSSEZ, P.A. (2006). A family of human zinc finger proteins that bind 


\section{K. Ikegami et al.}

methylated DNA and repress transcription. Mol Cell Biol 26: 169-181.

FISCHLE, W., WANG, Y., JACOBS, S.A., KIM, Y., ALLIS, C.D. and KHORASANIZADEH, S. (2003). Molecular basis for the discrimination of repressive methyl-lysine marks in histone $\mathrm{H} 3$ by Polycomb and HP1 chromodomains. Genes Dev 17: 1870-1881.

FOUSE, S.D., SHEN, Y., PELLEGRINI, M., COLE, S., MEISSNER, A., VAN NESTE, L., JAENISCH, R. and FAN, G. (2008). Promoter CpG methylation contributes to ES cell gene regulation in parallel with Oct4/Nanog, PcG complex, and histone H3 K4/K27 trimethylation. Cell Stem Cell 2: 160-169.

FUJITA, N., WATANABE, S., ICHIMURA, T., TSURUZOE, S., SHINKAI, Y., TACHIBANA, M., CHIBA, T. and NAKAO, M. (2003). Methyl-CpG binding domain 1 (MBD1) interacts with the Suv39h1-HP1 heterochromatic complex for DNA methylation-based transcriptional repression. J Biol Chem 278: 2413224138.

FUKS, F., HURD, P.J., DEPLUS, R. and KOUZARIDES, T. (2003a). The DNA methyltransferases associate with HP1 and the SUV $39 \mathrm{H} 1$ histone methyltransferase. Nucleic Acids Res 31: 2305-2312.

FUKS, F., HURD, P.J., WOLF, D., NAN, X., BIRD, A.P. and KOUZARIDES, T. (2003b). The methyl-CpG-binding protein MeCP2 links DNA methylation to histone methylation. $J$ Biol Chem 278: 4035-4040.

GIBBONS, R.J., MCDOWELL, T.L., RAMAN, S., O'ROURKE, D.M., GARRICK, D., AYYUB, H. and HIGGS, D.R. (2000). Mutations in ATRX, encoding a SWI/SNFlike protein, cause diverse changes in the pattern of DNA methylation. Nat Genet 24: 368-371.

GILBERT, N., THOMSON, I., BOYLE, S., ALLAN, J., RAMSAHOYE, B. and BICKMORE, W.A. (2007). DNA methylation affects nuclear organization, histone modifications, and linker histone binding but not chromatin compaction. $J$ Cell Biol 177: 401-411.

GISSELSSON, D., SHAO, C., TUCK-MULLER, C.M., SOGOROVIC, S., PALSSON E., SMEETS, D. and EHRLICH, M. (2005). Interphase chromosomal abnormalities and mitotic missegregation of hypomethylated sequences in ICF syndrome cells. Chromosoma 114: 118-126.

GOLL, M.G. and BESTOR, T.H. (2005). Eukaryotic cytosine methyltransferases. Annu Rev Biochem 74: 481-514.

GRUENBAUM, Y., CEDAR, H. and RAZIN, A. (1982). Substrate and sequence specificity of a eukaryotic DNA methylase. Nature 295: 620-622.

GRUENBAUM, Y., STEIN, R., CEDAR, H. and RAZIN, A. (1981). Methylation of CpG sequences in eukaryotic DNA. FEBS Lett 124: 67-71.

HATTORI, N., ABE, T., SUZUKI, M., MATSUYAMA, T., YOSHIDA, S., LI, E. and SHIOTA, K. (2004a). Preference of DNA methyltransferases for CpG islands in mouse embryonic stem cells. Genome Res 14: 1733-1740.

HATTORI, N., IMAO, Y., NISHINO, K., OHGANE, J., YAGI, S., TANAKA, S. and SHIOTA, K. (2007). Epigenetic regulation of Nanog gene in embryonic stem and trophoblast stem cells. Genes Cells 12: 387-396.

HATTORI, N., NISHINO, K., KO, Y.G., OHGANE, J., TANAKA, S. and SHIOTA, K. (2004b). Epigenetic control of mouse Oct-4 gene expression in embryonic stem cells and trophoblast stem cells. J Biol Chem 279: 17063-17069.

HAYAKAWA, T., HARAGUCHI, T., MASUMOTO, H. and HIRAOKA, Y. (2003). Cell cycle behavior of human HP1 subtypes: distinct molecular domains of HP1 are required for their centromeric localization during interphase and metaphase. $J$ Cell Sci 116: 3327-3338.

HISANO, M., OHTA, H., NISHIMUNE, Y. and NOZAKI, M. (2003). Methylation of $\mathrm{CpG}$ dinucleotides in the open reading frame of a testicular germ cell-specific intronless gene, Tact1/Actl7b, represses its expression in somatic cells. Nucleic Acids Res 31: 4797-4804.

HUANG, Y., FANG, J., BEDFORD, M.T., ZHANG, Y. and XU, R.M. (2006). Recognition of histone $\mathrm{H} 3$ lysine- 4 methylation by the double tudor domain of JMJD2A. Science 312: 748-751.

IKEGAMI, K., IWATANI, M., SUZUKI, M., TACHIBANA, M., SHINKAI, Y., TANAKA S., GREALLY, J.M., YAGI, S., HATTORI, N. and SHIOTA, K. (2007). Genomewide and locus-specific DNA hypomethylation in G9a deficient mouse embryonic stem cells. Genes Cells 12: 1-11.

IMAMURA, T., OHGANE, J., ITO, S., OGAWA, T., HATTORI, N., TANAKA, S. and SHIOTA, K. (2001). CpG island of rat sphingosine kinase-1 gene: tissuedependent DNA methylation status and multiple alternative first exons. Genomics 76: $117-125$
IMAMURA, T., YAMAMOTO, S., OHGANE, J., HATTORI, N., TANAKA, S. and SHIOTA, K. (2004). Non-coding RNA directed DNA demethylation of Sphk1 $\mathrm{CpG}$ island. Biochem Biophys Res Commun 322: 593-600.

IWASE, S., LAN, F., BAYLISS, P., DE LA TORRE-UBIETA, L., HUARTE, M., QI, H.H., WHETSTINE, J.R., BONNI, A., ROBERTS, T.M. and SHI, Y. (2007). The X-linked mental retardation gene SMCX/JARID1C defines a family of histone H3 lysine 4 demethylases. Cell 128: 1077-1088.

JACKSON, J.P., LINDROTH, A.M., CAO, X. and JACOBSEN, S.E. (2002). Control of CpNpG DNA methylation by the KRYPTONITE histone $\mathrm{H} 3$ methyltransferase. Nature 416: 556-560.

JANOWSKI, B.A., HUFFMAN, K.E., SCHWARTZ, J.C., RAM, R., HARDY, D., SHAMES, D.S., MINNA, J.D. and COREY, D.R. (2005). Inhibiting gene expression at transcription start sites in chromosomal DNA with antigene RNAs. Nat Chem Biol 1: 216-222.

JANUCHOWSKI, R., DABROWSKI, M., OFORI, H. and JAGODZINSKI, P.P. (2007). Trichostatin A down-regulate DNA methyltransferase 1 in Jurkat T cells Cancer Lett 246: 313-317.

JIN, S.G., GUO, C. and PFEIFER, G.P. (2008). GADD45A does not promote DNA demethylation. PLoS Genet 4: e1000013.

KANGASPESKA, S., STRIDE, B., METIVIER, R., POLYCARPOU-SCHWARZ, M., IBBERSON, D., CARMOUCHE, R.P., BENES, V., GANNON, F. and REID, G. (2008). Transient cyclical methylation of promoter DNA. Nature 452: 112-115.

KHULAN, B., THOMPSON, R.F., YE, K., FAZZARI, M.J., SUZUKI, M., STASIEK, E., FIGUEROA, M.E., GLASS, J.L., CHEN, Q., MONTAGNA, C. et al. (2006). Comparative isoschizomer profiling of cytosine methylation: the HELP assay. Genome Res 16: 1046-1055.

KIM, D.H., VILLENEUVE, L.M., MORRIS, K.V. and ROSSI, J.J. (2006). Argonaute1 directs siRNA-mediated transcriptional gene silencing in human cells. Nat Struct Mol Biol 13: 793-797.

KIM, G.D., NI, J., KELESOGLU, N., ROBERTS, R.J. and PRADHAN, S. (2002). Cooperation and communication between the human maintenance and de novo DNA (cytosine-5) methyltransferases. EMBO J 21: 4183-4195.

KIMURA, H. and SHIOTA, K. (2003). Methyl-CpG-binding protein, MeCP2, is a target molecule for maintenance DNA methyltransferase, Dnmt1. J Biol Chem 278: $4806-4812$

KLOSE, R.J. and BIRD, A.P. (2006). Genomic DNA methylation: the mark and its mediators. Trends Biochem Sci 31: 89-97.

KLOSE, R.J., YAMANE, K., BAE, Y., ZHANG, D., ERDJUMENT-BROMAGE, H., TEMPST, P., WONG, J. and ZHANG, Y. (2006). The transcriptional repressor JHDM3A demethylates trimethyl histone $\mathrm{H} 3$ lysine 9 and lysine 36. Nature 442: 312-316.

KOUZARIDES, T. (2007). Chromatin modifications and their function. Cell 128: 693-705.

KREMENSKOY, M., KREMENSKA, Y., OHGANE, J., HATTORI, N., TANAKA, S., HASHIZUME, K. and SHIOTA, K. (2003). Genome-wide analysis of DNA methylation status of $\mathrm{CpG}$ islands in embryoid bodies, teratomas, and fetuses. Biochem Biophys Res Commun 311: 884-890.

KURAMOCHI-MIYAGAWA, S., WATANABE, T., GOTOH, K., TOTOKI, Y., TOYODA A., IKAWA, M., ASADA, N., KOJIMA, K., YAMAGUCHI, Y., IJIRI, T.W. et al. (2008). DNA methylation of retrotransposon genes is regulated by Piwi family members MILI and MIWI2 in murine fetal testes. Genes Dev 22: 908-17.

LACHNER, M., O'CARROLL, D., REA, S., MECHTLER, K. and JENUWEIN, T. (2001). Methylation of histone H3 lysine 9 creates a binding site for HP1 proteins. Nature 410: 116-120.

LACHNER, M., O'SULLIVAN, R.J. and JENUWEIN, T. (2003). An epigenetic road map for histone lysine methylation. J Cell Sci 116: 2117-2124.

LEE, D.Y., NORTHROP, J.P., KUO, M.H. and STALLCUP, M.R. (2006). Histone H3 lysine 9 methyltransferase G9a is a transcriptional coactivator for nuclear receptors. J Biol Chem 281: 8476-8845.

LEE, T.I., JENNER, R.G., BOYER, L.A., GUENTHER, M.G., LEVINE, S.S., KUMAR, R.M., CHEVAlIER, B., JOHNSTONE, S.E., COLE, M.F., ISONO, K. et al. (2006). Control of developmental regulators by Polycomb in human embryonic stem cells. Cell 125: 301-313.

LEHNERTZ, B., UEDA, Y., DERIJCK, A.A., BRAUNSCHWEIG, U., PEREZBURGOS, L., KUBICEK, S., CHEN, T., LI, E., JENUWEIN, T. and PETERS, A.H. (2003). Suv39h-mediated histone H3 lysine 9 methylation directs DNA 
methylation to major satellite repeats at pericentric heterochromatin. Curr Biol 13: $1192-1200$.

LEONHARDT, H., PAGE, A.W., WEIER, H.U. and BESTOR, T.H. (1992). A targeting sequence directs DNA methyltransferase to sites of DNA replication in mammalian nuclei. Cell 71: 865-873.

LEVINE, A., YEIVIN, A., BEN-ASHER, E., ALONI, Y. and RAZIN, A. (1993). Histone $\mathrm{H} 1$-mediated inhibition of transcription initiation of methylated templates in vitro. J Biol Chem 268: 21754-21759.

LI, E., BESTOR, T.H. and JAENISCH, R. (1992). Targeted mutation of the DNA methyltransferase gene results in embryonic lethality. Cell 69: 915-926.

LI, H., RAUCH, T., CHEN, Z.X., SZABO, P.E., RIGGS, A.D. and PFEIFER, G.P. (2006a). The histone methyltransferase SETDB1 and the DNA methyltransferase DNMT3A interact directly and localize to promoters silenced in cancer cells. $J$ Biol Chem 281: 19489-19500.

LI, L.C., OKINO, S.T., ZHAO, H., POOKOT, D., PLACE, R.F., URAKAMI, S., ENOKIDA, H. and DAHIYA, R. (2006b). Small dsRNAs induce transcriptional activation in human cells. Proc Natl Acad Sci USA 103: 17337-17342.

LIEB, J.D., BECK, S., BULYK, M.L., FARNHAM, P., HATTORI, N., HENIKOFF, S., LIU, X.S., OKUMURA, K., SHIOTA, K., USHIJIMA, T. et al. (2006). Applying whole-genome studies of epigenetic regulation to study human disease. Cytogenet Genome Res 114: 1-15.

MARTIN, G.R. (1981). Isolation of a pluripotent cell line from early mouse embryos cultured in medium conditioned by teratocarcinoma stem cells. Proc Natl Acad Sci USA 78: 7634-7638.

MCARTHUR, M. and THOMAS, J.O. (1996). A preference of histone $\mathrm{H} 1$ for methylated DNA. EMBO J 15: 1705-1714.

MCGHEE, J.D. and GINDER, G.D. (1979). Specific DNA methylation sites in the vicinity of the chicken beta-globin genes. Nature 280: 419-420.

METIVIER, R., GALLAIS, R., TIFFOCHE, C., LE PERON, C., JURKOWSKA, R.Z., CARMOUCHE, R.P., IBBERSON, D., BARATH, P., DEMAY, F., REID, G. et al. (2008). Cyclical DNA methylation of a transcriptionally active promoter. Nature 452: $45-50$.

MIKKELSEN, T.S., KU, M., JAFFE, D.B., ISSAC, B., LIEBERMAN, E., GIANNOUKOS, G., ALVAREZ, P., BROCKMAN, W., KIM, T.K., KOCHE, R.P. et al. (2007). Genome-wide maps of chromatin state in pluripotent and lineagecommitted cells. Nature 448: 553-560.

MILNE, T.A., BRIGGS, S.D., BROCK, H.W., MARTIN, M.E., GIBBS, D., ALLIS, C.D. and HESS, J.L. (2002). MLL targets SET domain methyltransferase activity to Hox gene promoters. Mol Cell 10: 1107-1117.

MONTGOMERY, N.D., YEE, D., CHEN, A., KALANTRY, S., CHAMBERLAIN, S.J., OTTE, A.P. and MAGNUSON, T. (2005). The murine polycomb group protein Eed is required for global histone H3 lysine-27 methylation. Curr Biol 15: $942-$ 947.

MORRIS, K.V., CHAN, S.W., JACOBSEN, S.E. and LOONEY, D.J. (2004). Small interfering RNA-induced transcriptional gene silencing in human cells. Science 305: 1289-1292.

NAGANO, T., MITCHELL, J.A., SANZ, L.A., PAULER, F.M., FERGUSON-SMITH, A.C., FEIL, R. and FRASER, P. (2008). The Air noncoding RNA epigenetically silences transcription by targeting G9a to chromatin. Science 322: 1717-20.

NAN, X., HOU, J., MACLEAN, A., NASIR, J., LAFUENTE, M.J., SHU, X., KRIAUCIONIS, S. and BIRD, A. (2007). Interaction between chromatin proteins MECP2 and ATRX is disrupted by mutations that cause inherited mental retardation. Proc Natl Acad Sci USA 104: 2709-2714.

NAN, X., NG, H.H., JOHNSON, C.A., LAHERTY, C.D., TURNER, B.M., EISENMAN, R.N. and BIRD, A. (1998). Transcriptional repression by the methyl-CpGbinding protein MeCP2 involves a histone deacetylase complex. Nature 393: 386-389.

NIELSEN, S.J., SCHNEIDER, R., BAUER, U.M., BANNISTER, A.J., MORRISON, A., O'CARROLL, D., FIRESTEIN, R., CLEARY, M., JENUWEIN, T., HERRERA, R.E. et al. (2001). Rb targets histone H3 methylation and HP1 to promoters. Nature 412: 561-565.

NIGHTINGALE, K. and WOLFFE, A.P. (1995). Methylation at CpG sequences does not influence histone $\mathrm{H} 1$ binding to a nucleosome including a Xenopus borealis 5 S rRNA gene. J Biol Chem 270: 4197-4200.

NIWA, H., MIYAZAKI, J. and SMITH, A.G. (2000). Quantitative expression of Oct$3 / 4$ defines differentiation, dedifferentiation or self-renewal of ES cells. Nat
Genet 24: 372-376.

OAKES, C.C., LA SALLE, S., SMIRAGLIA, D.J., ROBAIRE, B. and TRASLER, J.M. (2007). Developmental acquisition of genome-wide DNA methylation occurs prior to meiosis in male germ cells. Dev Biol 307: 368-379.

O'CARROLL, D., ERHARDT, S., PAGANI, M., BARTON, S.C., SURANI, M.A. and JENUWEIN, T. (2001). The polycomb-group gene Ezh2 is required for early mouse development. Mol Cell Biol 21: 4330-4336.

OHGANE, J., HATTORI, N., ODA, M., TANAKA, S. and SHIOTA, K. (2002). Differentiation of trophoblast lineage is associated with DNA methylation and demethylation. Biochem Biophys Res Commun 290: 701-706.

OKANO, M., BELL, D.W., HABER, D.A. and LI, E. (1999). DNA methyltransferases Dnmt3a and Dnmt3b are essential for de novo methylation and mammalian development. Cell 99: 247-257.

OKANO, M., XIE, S. and LI, E. (1998). Cloning and characterization of a family of novel mammalian DNA (cytosine-5) methyltransferases. Nat Genet 19: 219220.

PANDEY, R.R., MONDAL, T., MOHAMMAD, F., ENROTH, S., REDRUP, L., KOMOROWSKI, J., NAGANO, T., MANCINI-DINARDO, D. and KANDURI, C. (2008). Kcnq1ot1 antisense noncoding RNA mediates lineage-specific transcriptional silencing through chromatin-level regulation. Mol Cell 32: 23246.

PASINI, D., BRACKEN, A.P., JENSEN, M.R., LAZZERINI DENCHI, E. and HELIN, K. (2004). Suz12 is essential for mouse development and for EZH2 histone methyltransferase activity. EMBO $J$ 23: 4061-4071.

PATNAIK, D., CHIN, H.G., ESTEVE, P.O., BENNER, J., JACOBSEN, S.E. and PRADHAN, S. (2004). Substrate specificity and kinetic mechanism of mammalian G9a histone H3 methyltransferase. J Biol Chem 279: 53248-53258.

PETERS, A.H., KUBICEK, S., MECHTLER, K., O'SULLIVAN, R.J., DERIJCK, A.A., PEREZ-BURGOS, L., KOHLMAIER, A., OPRAVIL, S., TACHIBANA, M., SHINKAI, Y. et al. (2003). Partitioning and plasticity of repressive histone methylation states in mammalian chromatin. Mol Cell 12: 1577-1589.

PETERS, A.H., O'CARROLL, D., SCHERTHAN, H., MECHTLER, K., SAUER, S., SCHOFER, C., WEIPOLTSHAMMER, K., PAGANI, M., LACHNER, M., KOHLMAIER, A. et al. (2001). Loss of the Suv39h histone methyltransferases impairs mammalian heterochromatin and genome stability. Cell 107: 323-337.

PROKHORTCHOUK, A., HENDRICH, B., JORGENSEN, H., RUZOV, A., WILM, M., GEORGIEV, G., BIRD, A. and PROKHORTCHOUK, E. (2001). The p120 catenin partner Kaiso is a DNA methylation-dependent transcriptional repressor. Genes Dev 15: 1613-1618.

ROBERTSON, K.D., AIT-SI-ALI, S., YOKOCHI, T., WADE, P.A., JONES, P.L. and WOLFFE, A.P. (2000). DNMT1 forms a complex with Rb, E2F1 and HDAC1 and represses transcription from E2F-responsive promoters. Nat Genet 25: 338342.

ROUGEUlle, C., CHAUMEIL, J., SARMA, K., ALLIS, C.D., REINBERG, D., AVNER, P. and HEARD, E. (2004). Differential histone H3 Lys-9 and Lys-27 methylation profiles on the X chromosome. Mol Cell Biol 24: 5475-54784.

ROUNTREE, M.R., BACHMAN, K.E. and BAYLIN, S.B. (2000). DNMT1 binds HDAC2 and a new co-repressor, DMAP1, to form a complex at replication foci. Nat Genet 25: 269-277.

RUTHENBURG, A.J., ALLIS, C.D. and WYSOCKA, J. (2007). Methylation of lysine 4 on histone $\mathrm{H} 3$ : intricacy of writing and reading a single epigenetic mark. $\mathrm{Mol}$ Cell 25: 15-30.

SAKAMOTO, H., KOGO, Y., OHGANE, J., HATTORI, N., YAGI, S., TANAKA, S. and SHIOTA, K. (2008). Sequential changes in genome-wide DNA methylation status during adipocyte differentiation. Biochem Biophys Res Commun 366: 360-366.

SAKAMOTO, H., SUZUKI, M., ABE, T., HOSOYAMA, T., HIMENO, E., TANAKA, S., GREALLY, J.M., HATTORI, N., YAGI, S. and SHIOTA, K. (2007). Cell typespecific methylation profiles occurring disproportionately in CpG-less regions that delineate developmental similarity. Genes Cells 12: 1123-1132.

SAMPATH, S.C., MARAZZI, I., YAP, K.L., KRUTCHINSKY, A.N., MECKLENBRAUKER, I., VIALE, A., RUDENSKY, E., ZHOU, M.M., CHAIT, B.T. and TARAKHOVSKY, A. (2007). Methylation of a histone mimic within the histone methyltransferase G9a regulates protein complex assembly. Mol Cell 27: 596-608.

SARRAF, S.A. and STANCHEVA, I. (2004). Methyl-CpG binding protein MBD1 


\section{K. Ikegami et al.}

couples histone $\mathrm{H} 3$ methylation at lysine 9 by SETDB1 to DNA replication and chromatin assembly. Mol Cell 15: 595-605

SCHUETTENGRUBER, B., CHOURROUT, D., VERVOORT, M., LEBLANC, B. and CAVALLI, G. (2007). Genome regulation by polycomb and trithorax proteins. Cell 128: 735-745.

SCHULTZ, D.C., AYYANATHAN, K., NEGOREV, D., MAUL, G.G. and RAUSCHER, F.J., 3RD. (2002). SETDB1: a novel KAP-1-associated histone H3, lysine 9specific methyltransferase that contributes to HP1-mediated silencing of euchromatic genes by KRAB zinc-finger proteins. Genes Dev 16: 919-932.

SEKI, Y., YAMAJI, M., YABUTA, Y., SANO, M., SHIGETA, M., MATSUI, Y., SAGA, Y., TACHIBANA, M., SHINKAI, Y. and SAITOU, M. (2007). Cellular dynamics associated with the genome-wide epigenetic reprogramming in migrating primordial germ cells in mice. Development 134: 2627-2638.

SELKER, E.U. (1998). Trichostatin A causes selective loss of DNA methylation in Neurospora. Proc Natl Acad Sci USA 95: 9430-9435.

SHARIF, J., MUTO, M., TAKEBAYASHI, S., SUETAKE, I., IWAMATSU, A., ENDO T.A., SHINGA, J., MIZUTANI-KOSEKI, Y., TOYODA, T., OKAMURA, K. et al. (2007). The SRA protein Np95 mediates epigenetic inheritance by recruiting Dnmt1 to methylated DNA. Nature 450: 908-912.

SHI, Y., SAWADA, J., SUI, G., AFFAR EL, B., WHETSTINE, J.R., LAN, F., OGAWA, H., LUKE, M.P. and NAKATANI, Y. (2003). Coordinated histone modifications mediated by a CtBP co-repressor complex. Nature 422: 735-738.

SHIOTA, K. (2004). DNA methylation profiles of CpG islands for cellular differentiation and development in mammals. Cytogenet Genome Res 105: 325-334.

SHIOTA, K., KOGO, Y., OHGANE, J., IMAMURA, T., URANO, A., NISHINO, K., TANAKA, S. and HATTORI, N. (2002). Epigenetic marks by DNA methylation specific to stem, germ and somatic cells in mice. Genes Cells 7: 961-969.

SHOGREN-KNAAK, M., ISHII, H., SUN, J.M., PAZIN, M.J., DAVIE, J.R. and PETERSON, C.L. (2006). Histone H4-K16 acetylation controls chromatin structure and protein interactions. Science 311: 844-847.

SMALLWOOD, A., ESTEVE, P.O., PRADHAN, S. and CAREY, M. (2007). Functional cooperation between HP1 and DNMT1 mediates gene silencing. Genes Dev 21: 1169-1178.

SOLAGE, A. and CEDAR, H. (1978). Organization of 5-methylcytosine in chromosomal DNA. Biochemistry 17: 2934-2938.

SONG, F., SMITH, J.F., KIMURA, M.T., MORROW, A.D., MATSUYAMA, T., NAGASE, H. and HELD, W.A. (2005). Association of tissue-specific differentially methylated regions (TDMs) with differential gene expression. Proc Natl Acad Sci USA 102: 3336-3341.

SQUAZZO, S.L., O'GEEN, H., KOMASHKO, V.M., KRIG, S.R., JIN, V.X., JANG, S.W., MARGUERON, R., REINBERG, D., GREEN, R. and FARNHAM, P.J. (2006). Suz12 binds to silenced regions of the genome in a cell-type-specific manner. Genome Res 16: 890-900.

SUZUKI, M., SATO, S., ARAI, Y., SHINOHARA, T., TANAKA, S., GREALLY, J.M., HATTORI, N. and SHIOTA, K. (2007). A new class of tissue-specifically methylated regions involving entire CpG islands in the mouse. Genes Cells 12: 1305-1314.

TACHIBANA, M., NOZAKI, M., TAKEDA, N. and SHINKAI, Y. (2007). Functional dynamics of $\mathrm{H} 3 \mathrm{~K} 9$ methylation during meiotic prophase progression. $E M B O \mathrm{~J}$ 26: 3346-3359

TACHIBANA, M., SUGIMOTO, K., FUKUSHIMA, T. and SHINKAI, Y. (2001). Set domain-containing protein, G9a, is a novel lysine-preferring mammalian histone methyltransferase with hyperactivity and specific selectivity to lysines 9 and 27 of histone H3. J Biol Chem 276: 25309-25317.

TACHIBANA, M., SUGIMOTO, K., NOZAKI, M., UEDA, J., OHTA, T., OHKI, M. FUKUDA, M., TAKEDA, N., NIIDA, H., KATO, H. et al. (2002). G9a histone methyltransferase plays a dominant role in euchromatic histone $\mathrm{H} 3$ lysine 9 methylation and is essential for early embryogenesis. Genes Dev 16: 17799171

TACHIBANA, M., UEDA, J., FUKUDA, M., TAKEDA, N., OHTA, T., IWANARI, H., SAKIHAMA, T., KODAMA, T., HAMAKUBO, T. and SHINKAI, Y. (2005). Histone methyltransferases G9a and GLP form heteromeric complexes and are both crucial for methylation of euchromatin at H3-K9. Genes Dev 19: 815-826.

TAMARU, H. and SELKER, E.U. (2001). A histone H3 methyltransferase controls DNA methylation in Neurospora crassa. Nature 414: 277-283.
TANAKA, S., KUNATH, T., HADJANTONAKIS, A.K., NAGY, A. and ROSSANT, J. (1998). Promotion of trophoblast stem cell proliferation by FGF4. Science 282: 2072-2075.

TARIQ, M., SAZE, H., PROBST, A.V., LICHOTA, J., HABU, Y. and PASZKOWSKI, J. (2003). Erasure of CpG methylation in Arabidopsis alters patterns of histone H3 methylation in heterochromatin. Proc Natl Acad Sci USA 100: 8823-8827.

TERRANOVA, R., AGHERBI, H., BONED, A., MERESSE, S. and DJABALI, M. (2006). Histone and DNA methylation defects at Hox genes in mice expressing a SET domain-truncated form of MII. Proc Natl Acad Sci USA 103: 6629-6634.

TING, A.H., SCHUEBEL, K.E., HERMAN, J.G. and BAYLIN, S.B. (2005). Short double-stranded RNA induces transcriptional gene silencing in human cancer cells in the absence of DNA methylation. Nat Genet 37: 906-910.

TOMIKAWA, J., FUKATSU, K., TANAKA, S. and SHIOTA, K. (2006). DNA methylation-dependent epigenetic regulation of dimethylarginine dimethylaminohydrolase 2 gene in trophoblast cell lineage. J Biol Chem 281: 12163-12169.

TROJER, P., and REINBERG, D. (2008). Beyond histone methyl-lysine binding: how malignant brain tumor (MBT) protein L3MBTL1 impacts chromatin structure. Cell Cycle 7: 578-585.

TSUMURA, A., HAYAKAWA, T., KUMAKI, Y., TAKEBAYASHI, S., SAKAUE, M., MATSUOKA, C., SHIMOTOHNO, K., ISHIKAWA, F., LI, E., UEDA, H.R. et al (2006). Maintenance of self-renewal ability of mouse embryonic stem cells in the absence of DNA methyltransferases Dnmt1, Dnmt3a and Dnmt3b. Genes Cells 11: $805-814$

VIRE, E., BRENNER, C., DEPLUS, R., BLANCHON, L., FRAGA, M., DIDELOT, C., MOREY, L., VAN EYNDE, A., BERNARD, D., VANDERWINDEN, J.M. et al (2006). The Polycomb group protein EZH2 directly controls DNA methylation. Nature 439: 871-874

WANG, H., AN, W., CAO, R., XIA, L., ERDJUMENT-BROMAGE, H., CHATTON, B., TEMPST, P., ROEDER, R.G. and ZHANG, Y. (2003). mAM facilitates conversion by ESET of dimethyl to trimethyl lysine 9 of histone $\mathrm{H} 3$ to cause transcriptional repression. $\mathrm{Mol}$ Cell 12: 475-487.

WEBER, M., DAVIES, J.J., WITTIG, D., OAKELEY, E.J., HAASE, M., LAM, W.L. and SCHUBELER, D. (2005). Chromosome-wide and promoter-specific analyses identify sites of differential DNA methylation in normal and transformed human cells. Nat Genet 37: 853-862.

WEBER, M., HELLMANN, I., STADLER, M.B., RAMOS, L., PAABO, S., REBHAN, M. and SCHUBELER, D. (2007). Distribution, silencing potential and evolutionary impact of promoter DNA methylation in the human genome. Nat Genet 39: 457-466.

XIN, Z., TACHIBANA, M., GUGGIARI, M., HEARD, E., SHINKAI, Y. and WAGSTAFF, J. (2003). Role of histone methyltransferase G9a in CpG methylation of the Prader-Willi syndrome imprinting center. J Biol Chem 278: 14996-5000.

XIONG, Y., DOWDY, S.C., PODRATZ, K.C., JIN, F., ATTEWELL, J.R., EBERHARDT, N.L. and JIANG, S.W. (2005). Histone deacetylase inhibitors decrease DNA methyltransferase-3B messenger RNA stability and down-regulate de novo DNA methyltransferase activity in human endometrial cells. Cancer Res 65: 2684-2689.

YAGI, S., HIRABAYASHI, K., SATO, S., LI, W., TAKAHASHI, Y., HIRAKAWA, T., WU, G., HATTORI, N., OHGANE, J., TANAKA, S. et al. (2008). DNA methylation profile of tissue-dependent and differentially methylated regions (T-DMRs) in mouse promoter regions demonstrating tissue-specific gene expression. Genome Res 18: 1969-78.

YANG, L., MEI, Q., ZIELINSKA-KWIATKOWSKA, A., MATSUI, Y., BLACKBURN, M.L., BENEDETTI, D., KRUMM, A.A., TABORSKY, G.J., JR. and CHANSKY, H.A. (2003). An ERG (ets-related gene)-associated histone methyltransferase interacts with histone deacetylases $1 / 2$ and transcription co-repressors $\mathrm{mSin} 3 \mathrm{~A} /$ B. Biochem J 369: 651-657.

YODER, J.A., WALSH, C.P. and BESTOR, T.H. (1997). Cytosine methylation and the ecology of intragenomic parasites. Trends Genet 13: 335-340.

ZARATIEGUI, M., IRVINE, D.V. and MARTIENSSEN, R.A. (2007). Noncoding RNAs and gene silencing. Cell 128: 763-776.

ZHU, H., GEIMAN, T.M., XI, S., JIANG, Q., SCHMIDTMANN, A., CHEN, T., LI, E. and MUEGGE, K. (2006). Lsh is involved in de novo methylation of DNA. EMBO J 25: $335-345$ 


\section{Further Related Reading, published previously in the Int. J. Dev. Biol.}

See our Special Issue Fertilization edited by Paul M. Wassarman and Victor D. Vacquier at: http://www.ijdb.ehu.es/web/contents.php?vol=52\&issue=5-6

\section{Chromatin remodeling in plant development}

José A. Jarillo, Manuel Piñeiro, Pilar Cubas and José M. Martínez-Zapater

Int. J. Dev. Biol. (2009) 53: doi: 10.1387/ijdb.072460jj

Genetic and epigenetic instability of human bone marrow mesenchymal stem cells expanded in autologous serum or fetal bovine serum

John-Arne Dahl, Shivali Duggal, Neralie Coulston, Douglas Millar, John Melki, Aboulghassem Shahdadfar, Jan E. Brinchmann and Philippe Collas

Int. J. Dev. Biol. (2008) 52: 1033-1042

Expression of DjXnp, a novel member of the SNF2-like ATP-dependent chromatin remodelling genes, in intact and regenerating planarians.

Leonardo Rossi, Paolo Deri, Ilaria Andreoli, Vittorio Gremigni, Alessandra Salvetti and Renata Batistoni

Int. J. Dev. Biol. (2003) 47: 293-298

DNA methylation of the U2af1-rs1 gene in embryonic stem cells and embryonal carcinoma cells after RA-induced differentiation and apoptosis N Andollo, MD Boyano, A Asumendi, MM Zalduendo, J Arechaga Int. J. Dev. Biol. (2001) 45: S149-S150

DNA methylation and polyamines in embryonic development and cancer. O Heby

Int. J. Dev. Biol. (1995) 39: 737-757

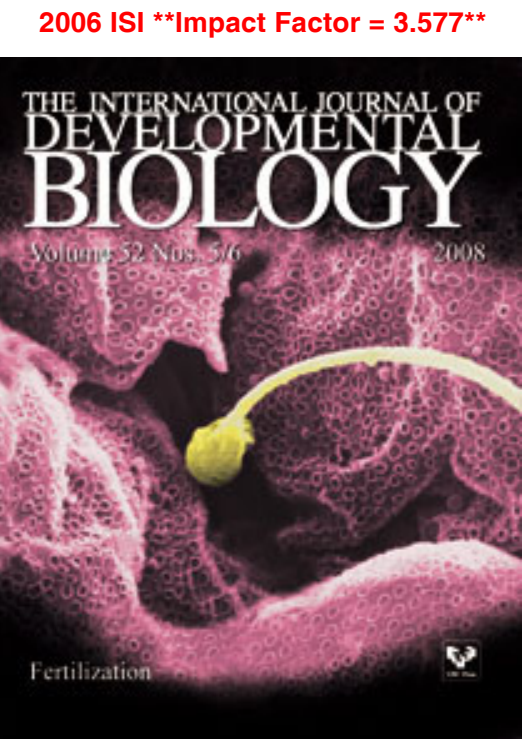

